\title{
Journal of Natural Products
}

dx.doi.org/10.1021/np3007827

|

\section{Cryptocapsinepoxide-type Carotenoids from Red Mamey,}

\section{Pouteria sapota}

Gergely Gulyás-Fekete, ${ }^{\dagger}$ Enrique Murillo, ${ }^{\ddagger}$ Tibor Kurtán, ${ }^{\S}$ Tamás Papp,${ }^{\S}$ Tünde-Zita Illyés, ${ }^{\S}$ László Drahos, ${ }^{\perp}$ Júlia Visy, ${ }^{\|}$Attila Agócs, ${ }^{\dagger}$ Erika Turcsi, ${ }^{\dagger}$ and József Deli†,*

'Department of Biochemistry and Medical Chemistry, Medical School, University of Pécs, Szigeti út 12, 7624, Pécs, Hungary,

Department of Biochemistry, Faculty of Exact Natural Sciences and Technology, University of Panama, Panama City, Panama,

${ }^{\S}$ Department of Organic Chemistry, Faculty of Sciences, University of Debrecen, Egyetem tér 1, 4032 Debrecen, Hungary

${ }^{\perp}$ Institute of Organic Chemistry, Research Centre for Natural Sciences, Hungarian Academy of Sciences, Pusztaszeri út 59-67, 1025 Budapest, Hungary

" Institute of Molecular Pharmacology, Research Centre for Natural Sciences, Hungarian Academy of Sciences, Pusztaszeri út 59-67, 1025 Budapest, Hungary 


\begin{abstract}
Three new carotenoids, cryptocapsin-5,6-epoxide, 3'-deoxycapsanthin-5,6-epoxide, and cryptocapsin-5,8-epoxides, have been isolated from the ripe fruits of red mamey (Pouteria sapota). Cryptocapsin-5,6-epoxide was prepared by partial synthesis via epoxidation of cryptocapsin and the $(5 R, 6 S)$ - and $(5 S, 6 R)$-stereoisomers were identified by HPLC-ECD analysis. Spectroscopic data of the natural (anti) and semisynthetic (syn) derivatives obtained by acid-catalyzed rearrangement of cryptocapsin-5,8-epoxide stereoisomers were compared for structural elucidation. Chiral HPLC separation of natural and semisynthetic samples of cryptocapsin-5,8-epoxides was performed and HPLC-ECD analysis allowed configurational assignment of the separated stereoisomers.
\end{abstract}

Carotenoids containing a $\kappa$-end group such as capsanthin (1), capsorubin (2), and cryptocapsin (3) occur mainly in red paprika (Capsicum annuum) $\cdot{ }^{1-3}$ Capsanthin (1) has also been found in the pollen anthers of Lilium tigrinum, ${ }^{4,5}$ in the fruit of Berberis spp., ${ }^{6}$ as well as Asparagus officinalis. ${ }^{7,8}$ Capsorubin (2) has also been isolated from the integument of Encephalartos altensteinil, petals of Cajophora lateritia, ${ }^{9}$ and the fruits of A. officinalis. ${ }^{7,8}$

Earlier we reported the isolation and characterization of a range of carotenoids with a $\kappa$-end group from red paprika including capsanthin-5,6-epoxide, ${ }^{10}$ capsanthin-3,6-epoxide, ${ }^{10,11}$ 5,6diepicapsokarpoxanthin, ${ }^{5,12}$ and capsoneoxanthin, ${ }^{13}$ which contained 5,6-epoxy-, 3,6-epoxy-, 3,5,6-trihydroxy- $\beta$ and allenic end groups, respectively. While the $\kappa$-ring is hydroxylated in these carotenoids, Maoka and his co-workers ${ }^{14}$ have identified two carotenoids with a nonhydroxylated $\kappa$-ring from red paprika. A survey of local plants in Panama has revealed the presence of ketocarotenoids in a range of species. Plants with high concentrations of ketocarotenoids have been reported in fruits such as 'mamey' (Pouteria sapota), 'maracuya chino' (Cionosicyos macranthus), 'jipijapa' (Carludovica palmata), and in young red-brown leaves and red seeds of Zamia dressleri. ${ }^{15}$

We have reported the isolation of sapotexanthin $\left[(5 R)-\beta\right.$, $\kappa$-caroten-6-one, (4)], ${ }^{16} 3^{\prime}-$ deoxycapsorubin, and 3,3'-dideoxycapsorubin, ${ }^{17}$ from the panamian fruit mamey (Pouteria sapota), which are carotenoids with non-hydroxylated $\kappa$-end groups. The structural elucidation of these carotenoids was accomplished by MS, electronic circular dichroism (ECD), and NMR methods. ${ }^{16,17}$ It was also established that the mamey fruit contains several carotenoids with a $\kappa$-end group including cryptocapsin (3) as the main carotenoid component. $^{18}$ 
Herein, the isolation of the new carotenoids cryptocapsin-5,6-epoxide (5), 3'deoxycapsanthin-5,6-epoxide (6), and cryptocapsin-5,8-epoxides $(\mathbf{1 1}, \mathbf{1 2})$ is reported from the fruits of red mamey. Cryptocapsin-5,6-epoxide (5) was prepared by the epoxidation of cryptocapsin (3) as a reference compound. Spectroscopic data of natural (anti, 5) and semisynthetic $(s y n, 7)$ compounds were analyzed for structural elucidation.

\section{RESULTS AND DISCUSSION}

Red mamey was extracted according to published procedures. ${ }^{16}$ Repeated column chromatography of the mamey extract on $\mathrm{Al}_{2} \mathrm{O}_{3}$ and $\mathrm{CaCO}_{3}$ yielded $8 \mathrm{mg}$ cryptocapsin (3), 4 mg cryptocapsin-5,6-epoxide (5), $0.5 \mathrm{mg}$ 3'-deoxycapsanthin-5,6-epoxide (6), $0.5 \mathrm{mg} \beta$ cryptoxanthin-5,6,5',6'-diepoxide (8), and $1.5 \mathrm{mg}$ of an epimeric mixture of cryptocapsin-5,8epoxides $(\mathbf{1 1}, \mathbf{1 2})$.

\section{Structure Elucidation of the Natural Cryptocapsin-5,6-epoxide (5)}

The structure of cryptocapsin-5,6-epoxide (5) was established from its UV-VIS, ECD, MS, and ${ }^{1} \mathrm{H}$ and ${ }^{13} \mathrm{C}-\mathrm{NMR}$ data. The UV-VIS spectrum ( $\lambda_{\max }: 480$ and $505 \mathrm{sh} \mathrm{nm}$ in benzene) was in agreement with a decaene chromophore containing a conjugated carbonyl group. Reduction of cryptocapsin-5,6-epoxide (5) with $\mathrm{NaBH}_{4}$ gave an approximately 1:1 mixture of the corresponding stereoisomeric alcohols. The UV-VIS spectrum of this mixture exhibited welldefined fine structure and a hypsochromic shift ( $\lambda_{\max }: 426,451,481 \mathrm{~nm}$ in benzene). Upon treatment with $\mathrm{HCl} / \mathrm{HOAc}$, the $464,486 \mathrm{~nm} \lambda_{\max }$ value of the resultant product indicated the presence of a 5,6-epoxy group. The HPLC-MS and HRESITOFMS of 5 showed a molecular ion at $m / z$ 584.4241, which corresponds to the formula $\mathrm{C}_{40} \mathrm{H}_{56} \mathrm{O}_{3}$. Owing to the rapid rearrangement of the 5,6-epoxy to the 5,8-epoxy group during NMR experiments, ${ }^{1} \mathrm{H},{ }^{1} \mathrm{H}$ COSY and ${ }^{13} \mathrm{C}$ NMR data could not be recorded. Thus, NMR analysis was restricted to the protons of the end-groups in $\mathbf{5}$. The ${ }^{1} \mathrm{H}$ NMR chemical shifts of $\mathbf{5}$ were compared with those of semisynthetic $\beta$-cryptoxanthin-5',6'-epoxide ${ }^{19}$ (9) and capsanthin-5,6-epoxide ${ }^{20}$ (10). ${ }^{1} \mathrm{H}$ NMR experiments of 5 revealed the presence of a 5,6-epoxy- $\beta$ end group, a 3-hydroxy-6-oxo$\kappa$ end group, and an all-E polyene chain. Because the NMR data of the syn and anti epoxides are identical, the assignments are only given for the semisynthetic compound. Since the diastereomers with non-hydroxylated $(5 R, 6 S)$ or $(5 S, 6 R)-5,6$-epoxy- $\beta$ end groups cannot be distinguished by their ${ }^{1} \mathrm{H}$ NMR spectra, the configurational assignment of the cyclohexane ring was based on chiroptical data. 
The ECD spectra of carotenoid-5,6-epoxides are governed by the configuration of C-5 and C6 , and additional substituents of the $\beta$-end group have no significant influence on the ECD transitions. The influence of the additional $\kappa$-end group on the ECD spectra is also rather small, and hence the absolute configuration of the 5,6-epoxy group could be determined unambiguously. ${ }^{21}$ The natural cryptocapsin 5,6-epoxide (5) gave positive Cotton effects (CEs) at 207, 242 and $349 \mathrm{~nm}$ and negative ones at 215 and $281 \mathrm{~nm}$, which is in agreement with the ECD data of natural capsanthin-(3S,5R,6S)-5,6-epoxide (10). ${ }^{20}$ Consequently, the ECD spectra confirmed the $(5 R, 6 S)$ configuration of natural cryptocapsin-5,6-epoxide (5) (Figure $1)$.

\section{Epoxidation of Cryptocapsin (3)}

In order to characterize the natural cryptocapsin-5,6-epoxide (5), it was synthesized from cryptocapsin (3) by epoxidation with monoperoxophthalic acid. The epoxidation produced two diastereomeric 5,6-epoxides with $(5 R, 6 S)$ and $(5 S, 6 R)$ absolute configurations. ${ }^{19,20}$ The separation of such diasteromeric epoxides with unsubstituted $\beta$-ring is usually not considered straightforward. However, in our case, base-line separation of $(5 R, 6 S)$ - and $(5 S, 6 R)$ cryptocapsin-5,6-epoxide diastereomers (5 and 7, respectively) was achieved on a Chiralcel OD HPLC column, which showed $c a$. equal amounts of the two diasteromers (Figure 2).

The OR-detected HPLC chromatogram showed that both diastereomers had positive optical rotation and hence this optical parameter was not suitable to distinguish them. Since online HPLC-ECD measurements had been shown an efficient tool for studying stereoisomeric mixtures of natural products, ${ }^{22-24}$ this technique was employed in separation of diastereomers 5 and 7. The HPLC-ECD chromatogram (Figure 2a, upper curve) recorded at $280 \mathrm{~nm}$ showed opposite CEs for the two diastereomers. Online HPLC-ECD spectra were recorded by stopping the flow of the eluent in the HPLC-ECD flow cell at the maximum concentration of the separated diastereomers. The diastereomers had near mirror image ECD curves above 250 $\mathrm{nm}$ allowing the configurational assignment of the synthetic diastereomers (Figure 3).

The CEs of natural (anti, 5) and semisynthetic (syn, 7) cryptocapsin 5,6-epoxides had opposite signs above $250 \mathrm{~nm}$ reflecting the different configuration of the 5,6-epoxy-end groups. These data corroborated well the reported values of anti and syn-capsanthin-5,6epoxide. $^{20} 1 \mathrm{D}$ and $2 \mathrm{D}$ NMR analysis was also performed for the diastereomeric mixture of (5R,6S)- and (5S,6R)-cryptocapsin-5,6-epoxides 5 and 7. The ${ }^{1} \mathrm{H}$ and ${ }^{13} \mathrm{C}$ signals were assigned by means of $2 \mathrm{D}{ }^{1} \mathrm{H} \mathrm{COSY},{ }^{13} \mathrm{C}$ HSQC and ${ }^{13} \mathrm{C}$ HMBC spectra. The proton chemical 
shifts of the end groups (H-7 at $\delta 5.90 \mathrm{ppm}, \mathrm{H}-8$ at $\delta 6.29 \mathrm{ppm}$ ) and the ${ }^{3} J_{\mathrm{H}, \mathrm{H}}$ coupling constants $\left(J_{7,8}=15.4 \mathrm{~Hz}\right)$ were identical with the corresponding data of the natural $(5 R, 6 S)$ cryptocapsin-5,6-epoxide (5). HSQC experiments revealed the presence of 5,6-epoxy- $\beta$ and 3hydroxy-6-oxo- $\kappa$ end groups, since $\mathrm{H}-3^{\prime}$ resonated at $4.51 \mathrm{ppm}$ as a multiplet and C-3' at 70.4 ppm. $^{25}$

\section{Structure Elucidation of 3'-Deoxycapsanthin-5,6-epoxide (6)}

The 3'-deoxycapsanthin-5,6-epoxide (6) showed a similar UV-VIS spectrum to that of cryptocapsin-5,6-epoxide (5) [ $\lambda_{\max }: 480$ and 505(sh) nm in benzene, which is shifted to 464 , $486 \mathrm{~nm}$ after acid treatment in benzene]. The HRESITOFMS exhibited a parent ion at $\mathrm{m} / \mathrm{z}$ 584.4232, which corresponded to the formula $\mathrm{C}_{40} \mathrm{H}_{56} \mathrm{O}_{3}$. Owing to the small amount of sample available, this compound was characterized only by ${ }^{1} \mathrm{H}$ NMR. ${ }^{1} \mathrm{H}$ chemical shifts of the end groups and ${ }^{3} J_{\mathrm{H}, \mathrm{H}}$ coupling constants were compared with those of sapotexanthin ${ }^{16}$ (4) and capsanthin-5,6-epoxide (10), ${ }^{20}$ confirming the proposed structure. The proton signal at $\delta 3.93$ and ${ }^{3} J_{\mathrm{H}, \mathrm{H}}$ values of the 3-hydroxy- $\beta$-end group were identical with the corresponding literature data. ${ }^{19,20}$ These data indicated that the hydroxy group is attached to the cyclohexane ring ( $\delta 3.93$ for $\mathrm{H}-3) .{ }^{25}$ The ${ }^{1} \mathrm{H}$ signals of the 14 olefinic protons were only partially assigned. The ECD spectrum of 3'-deoxycapsanthin-5,6-epoxide (6) showed positive CEs at 240 and 347 $\mathrm{nm}$ and negative ones at 214 and $280 \mathrm{~nm}$, which were in agreement with the ECD data of natural capsanthin-5,6-epoxide. ${ }^{20}$ Thus, the ECD spectrum confirmed the $(5 R, 6 S)$ absolute configuration of 6 (Figure 1). Based on the NMR and ECD data, 6 was identified as (all$E, 3 S, 5 R, 6 S, 5^{\prime} R$ )-3-hydroxy- $\beta, \kappa$-caroten-6'-one, for which the 3'-deoxycapsanthin-5,6-epoxide trivial name is proposed.

\section{Structural Elucidation of $\beta$-Cryptoxanthin-5,6,5', $6^{\prime}$-diepoxide (8)}

In the UV-VIS spectra of $\mathbf{8}$, the 428,453 , and $483 \mathrm{~nm}$ maxima in benzene and the fine structures were in accordance with the reported data for $\beta$-cryptoxanthin-5,6,5',6'-diepoxide. ${ }^{19}$ On acidic treatment, 8 underwent furanoid rearrangement and the rearranged product had characteristic absorption maxima at 388, 410, $436 \mathrm{~nm}$ in benzene. The identification of $\mathbf{8}$ was based on comparison with NMR data published by our group for the corresponding 5,6-epoxy end groups. ${ }^{19}$ The ECD spectrum of $\mathbf{8}$ was similar to that of the reported spectrum, ${ }^{19}$ hence confirming the $\left(3 R, 5 R, 6 S, 5^{\prime} R, 6^{\prime} S\right)$ absolute configuration (Figure 1$)$. 


\section{Structural Elucidation of Cryptocapsin-5,8-epoxides $(11,12)$}

The UV-VIS spectrum of the mixture of 11 and 12 ( $\lambda_{\max }: 464$ and $486 \mathrm{~nm}$ in benzene) was in agreement with a nonaene chromophore containing a conjugated carbonyl group. The HPLCMS exhibited a parent ion signal at $m / z 584.42$, which corresponded to a molecular formula of $\mathrm{C}_{40} \mathrm{H}_{56} \mathrm{O}_{3}$. The HPLC analysis of this compound showed two peaks with identical UV-VIS spectra indicating the presence of two stereoisomers with $(5 R, 8 S)$ and $(5 R, 8 R)$ absolute configuration. However, these stereoisomers could not be separated by column chromatography using a $\mathrm{CaCO}_{3}$ stationary phase. The proton chemical shifts and coupling constants, and ${ }^{13} \mathrm{C}$ chemical shifts of the 5,8-epoxy- $\beta$-end group were identical with the reported data. ${ }^{25,26}$ Pairs of doublets appearing at 5.16 and 5.24 ppm (H-7) as well as at 5.18 and $5.08 \mathrm{ppm}(\mathrm{H}-8)$ confirmed the presence of the two stereoisomers with $\sim 2: 1$ ratio. The ${ }^{1} \mathrm{H}$ and ${ }^{13} \mathrm{C}$ chemical shift values of $\mathrm{H}-8$ and $\mathrm{C}-7$ of the $\beta$-end group of $\mathbf{1 1}$ and $\mathbf{1 2}$ were different, which suggested different configuration of C-8. Owing to their complexity, the ${ }^{13} \mathrm{C}$ NMR signals of 11 and 12 were only partially assigned and ${ }^{13} \mathrm{C}$ NMR data could not be obtained for the quaternary carbons.

The base-line separation of $\mathbf{1 1}$ and $\mathbf{1 2}$ was achieved on a Chiralpak IC column. The UV chromatogram showed that the two epoxides had a 1:1.8 ratio (Figure 4). Since the amount of sample was not sufficient for multiple injections and online HPLC-ECD analysis, the authentic samples of $\mathbf{1 1}$ and $\mathbf{1 2}$ had to be synthesized. This was accomplished by acidcatalyzed rearrangement of the stereoisomeric mixture of cryptocapsin-5,6-epoxides $\mathbf{5}$ and 7, which afforded a stereoisomeric mixture of cryptocapsin-5,8-epoxides (11-14). A base-line HPLC separation of the resulting four stereoisomeric cryptocapsin-5,8-epoxides (11-14) was achieved on a Chiralpak IC column (Figure 4) using the same HPLC conditions that were developed for the separation of $(5 R, 8 S)-11$ and $(5 R, 8 R)-12$. The HPLC analysis of synthetic epoxides showed a 1:2.7:1.1:2.3 ratio of the stereoisomers. Comparison of the HPLC profiles of natural and synthetic cryptocapsin-5,8-epoxides permitted the identification of synthetic $(5 R, 8 S)-\mathbf{1 1}$ and $(5 R, 8 R)-\mathbf{1 2}$ as the the first- and fourth-eluting stereoisomers, respectively. The absolute configurations of $\mathbf{1 1}$ and $\mathbf{1 2}$ were assigned on the basis of their online HPLC-ECD spectra. On the basis of reported ECD data of natural $(5 R, 6 S)$-cryptocapsin 5,6-epoxide $(\mathbf{5}),{ }^{27}$ the $(5 R)$ absolute configuration was assigned for both 11 and 12. Moreover, the onle HPLCECD spectra of 11 and 12 showed opposite CEs at 204 and $267 \mathrm{~nm}$, which suggested $(5 R, 8 S)$ absolute configuration for the first-eluting stereoisomer $[(5 R, 8 S)-11]$ and $(5 R, 8 R)$ for the 
fourth-eluting one $[(5 R, 8 R)-12]$ in accordance with the literature data of furanoid derivatives. ${ }^{28}$ The second-eluting stereoisomers 13 and the third-eluting 14 had $(5 S)$ absolute configuration, and hence they were identified as $(5 S, 8 R)-\mathbf{1 3}$ and $(5 S, 8 S)-\mathbf{1 4}$ (Fig. 5).

\section{Biosynthesis}

The formation of 3-hydroxy- $\kappa$-end group from a 3-hydroxy-5,6-epoxy- $\beta$-end group by pinacol rearrangement is a well known biosynthetic route. ${ }^{29}$ Capsanthin (1), capsorubin (2), and cryptocapsin (3) are formed by this transformation from antheraxanthin, violaxanthin, and $\beta$-cryptoxanthin-5,6-epoxide, respectively. ${ }^{2}$ Carotenoids possessing a 5,6-epoxy functional group in their hydroxylated $\beta$-rings are quite common in nature. However, carotenoids with 5,6-epoxy groups in a non-hydroxylated $\beta$-ring have been rarely reported. In the red mamey, the presence of carotenoids containing no hydroxylated $\kappa$-rings can be attributed to the coincidence of two rare metabolic events: 1) high activity of enzymes catalyzing the epoxidation of non-hydroxylated $\beta$-rings and 2) enzyme-catalyzed pinacol rearrangement of epoxides. The high concentration of $\beta$-cryptoxanthin-5,6,5',6'-diepoxide (8) that contains hydroxylated and non-hydroxylated 5,6-epoxy- $\beta$-rings facilitates the formation of cryptocapsin-5,6-epoxide (5) and 3'-deoxycapsanthin-5,6-epoxide (6) (Scheme 1).

\section{EXPERIMENTAL SECTION}

General Experimental Procedures: The UV-VIS spectra were recorded with a Jasco V-530 spectrophotometer in benzene. The exact mass measurements (HRESITOFMS) were performed using a Waters Q-TOF Premier mass spectrometer (Waters Corporation, 34 Maple St, Milford, MA, USA). The sample was dissolved in $\mathrm{MeOH}$ and measured in positive electrospray ionization mode.

The ${ }^{1} \mathrm{H}(400 \mathrm{MHz})$ and ${ }^{13} \mathrm{C}$ NMR $(100 \mathrm{MHz})$ spectra were measured with a Varian UNITY INOVA 400-WB spectrometer and on a Bruker DRX Avance II $\left(500 / 125 \mathrm{MHz}\right.$ for $\left.{ }^{1} \mathrm{H} /{ }^{13} \mathrm{C}\right)$ spectrometer. Chemical shifts are referenced to internal TMS $\left({ }^{1} \mathrm{H}\right)$, or to the residual solvent signals $\left({ }^{13} \mathrm{C}\right)$. ECD spectra were recorded at room temperature with a J-810 spectropolarimeter.

HPLC-DAD Analysis: The HPLC system was interfaced into gradient pump Dionex P680, equipped with a Dionex PDA-100 detector and the data were processed by Chromeleon 6.70 software. The HPLC separations were carried out on an endcapped C30 column ( $250 \mathrm{x}$ 


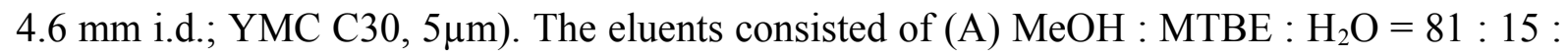
4 and (B) $\mathrm{MeOH}: \mathrm{MTBE}: \mathrm{H}_{2} \mathrm{O}=6: 90: 4$. The chromatographic separation were carried out using a linear gradient consisting of $100 \%$ eluent $\mathrm{A}$ at time zero that was changed to $50 \%$ eluent $B$ within 45 minute at a flow rate of $1 \mathrm{~mL} / \mathrm{min}$.

Chiral HPLC and HPLC-ECD Analysis: Chiral HPLC separations were carried out with a Jasco HPLC system on Chiralcel OD column $(0.46 \mathrm{~cm} \times 25 \mathrm{~cm}, 5 \mu \mathrm{m})$ using $n$-hexane:EtOH $=1: 1$ at a flow rate of $0.5 \mathrm{~mL} / \mathrm{min}$ for 5 and 7 or Chiralcel IC $(5 \mu \mathrm{m}, 150 \times 4.6 \mathrm{~mm})$ with $n$ hexane:EtOH $=8: 2$ at a flow rate of $1.0 \mathrm{~mL} / \mathrm{min}$ for 11-14. HPLC-UV and OR chromatograms were measured with a Jasco MD-910 multiwavelength and OR-2090Plus chiral detector, respectively. The baseline of the chromatograms were zeroed immediately after the start of each run; this allowed the measurement of the relative absorbance or optical rotation. The HPLC-ECD traces were recorded at the specified wavelength with a Jasco J-810 ECD spectropolarimeter equipped with a $1 \mathrm{~cm}$ path length HPLC flow cell and the baseline was zeroed after the start of each run. The on-line ECD and UV spectra were recorded simultaneously by stopping the flow at the UV absorption maximum of each peak. ECD ellipticity values $(\phi)$ were not corrected for concentration. For an HPLC-ECD spectrum, three consecutive scans were recorded and averaged with $2 \mathrm{~nm}$ bandwidth, $1 \mathrm{~s}$ response, and standard sensitivity. The HPLC-ECD spectrum of the eluent was recorded in the same way. The concentration of the injected sample was set so that the HT (voltage) value did not exceed $500 \mathrm{~V}$ in the HT channel.

Plant Material. Matured fruits were purchased from the Metropolitan public market in Panama City, Panama.

Extraction and Isolation: The pulp of red mamey (500 g) was homogenized in a porcelain mortar with $50 \mathrm{~g}$ of $\mathrm{NaHCO}_{3}$ and extracted with acetone until the extract was colorless. The extract was diluted with a mixture of $\mathrm{Et}_{2} \mathrm{O} / n$-hexane (1:1), washed with $\mathrm{H}_{2} \mathrm{O}$ to remove acetone, dried over $\mathrm{Na}_{2} \mathrm{SO}_{4}$, and evaporated to dryness. The residue was dissolved in $\mathrm{Et}_{2} \mathrm{O}$ and saponified with methanolic $\mathrm{KOH}$. After saponification, the ethereal solution was washed with $\mathrm{H}_{2} \mathrm{O}$ and evaporated. The residue was subjected to open column chromatography $\left(\mathrm{Al}_{2} \mathrm{O}_{3}\right.$ Brokman grade III) using an increasing percentage of $\mathrm{Et}_{2} \mathrm{O}$ in $n$-hexane. Cryptocapsin5,6-epoxide (5), 3'-deoxycapsanthin-5,6-epoxide (6) cryptoxanthin-5,6,5',6'-diepoxide (8), and cryptocapsin-5,8-epoxides $(\mathbf{1 1}, \mathbf{1 2})$ were isolated in pure form by additional column chromatography of Fraction 7 that was eluted with $50 \% \mathrm{Et}_{2} \mathrm{O}$ in $n$-hexane. The purity of the compounds was verified by HPLC-DAD. 
Fraction 7 was subjected to open column chromatography $\left(\mathrm{CaCO}_{3}\right.$ Biogal, Hungary, toluene: $n$-hexane $=30: 70)$. After development five fractions were visible: Fraction 71: $10 \mathrm{~mm}$ brick red band (mixture of cryptocapsin-5,8-epoxides $(\mathbf{1 1}, \mathbf{1 2})$ and $3^{\prime}$-deoxycapsorubin ${ }^{17}$ ); Fraction 72: $10 \mathrm{~mm}$ pink band: cryptocapsin-5,6-epoxide (5); Fraction 73: $20 \mathrm{~mm}$ red band cryptocapsin (3); Fraction 74: $10 \mathrm{~mm}$ pink band 3'-deoxycapsanthin-5,6-epoxide (6); and Fraction 75: $3 \mathrm{~mm}$ yellow band cryptoxanthin-5,6,5',6'-diepoxide (8).

After processing that consisted of cutting the column packing into sections and extracting each section, Fractions 72-75 were obtained that were crystallized from benzene and $n$-hexane yielding $4 \mathrm{mg}$ of cryptocapsin-5,6-epoxide (5), $8 \mathrm{mg}$ of cryptocapsin (3), 0,5 $\mathrm{mg}$ of 3'deoxycapsanthin-5,6-epoxide (6), and $0.5 \mathrm{mg}$ of cryptoxanthin 5,6,5',6'-diepoxide (8).

The zone containing cryptocapsin-5,8-epoxides $(\mathbf{1 1}, \mathbf{1 2})$ was subsequently subjected to a second OCC separation $\left(\mathrm{CaCO}_{3}\right.$ Biogal, Hungary, $4 \%$ acetone in $n$-hexane). After development, the following fractions were obtained: $5 \mathrm{~mm}$ red band ( 3 '-deoxycapsorubin), 7 $\mathrm{mm}$ yellow band $(\mathbf{1 1}, \mathbf{1 2})$. After desorption the mixture of cryptocapsin-5,8-epoxides $(\mathbf{1 1}, \mathbf{1 2})$ was crystallized (benzene- $n$-hexane $1: 10$ ) to give $1.5 \mathrm{mg}$ of red crystals.

Preparation of Semisynthetic Cryptocapsin-5,6-epoxides: To a solution of cryptocapsin acetate $(21 \mathrm{mg})$ in $\mathrm{Et}_{2} \mathrm{O}(80 \mathrm{~mL})$ at room temperature, $c a .0 .005 \mathrm{M}$ monoperoxyphthalic acid in $\mathrm{Et}_{2} \mathrm{O}(5 \mathrm{ml})$ was added. The mixture was kept under $\mathrm{N}_{2}$, in the dark, and after 6 and 10 h, respectively, additional monoperoxyphthalic acid solution ( 5 and 8 $\mathrm{mL}$ ) was added. After $20 \mathrm{~h}$, the mixture was washed with $5 \%$ aq. $\mathrm{NaHCO}_{3}$ solution, the organic phase was dried $\left(\mathrm{Na}_{2} \mathrm{SO}_{4}\right)$, and a $30 \% \mathrm{KOH} / \mathrm{MeOH}$ solution $(100 \mathrm{~mL})$ was added. After $16 \mathrm{~h}$, the solution was washed with $\mathrm{H}_{2} \mathrm{O}$ until neutral, dried $\left(\mathrm{Na}_{2} \mathrm{SO}_{4}\right)$, and evaporated. Crystallization from benzene and $n$-hexane (ratio 1:10) yielded $5 \mathrm{mg}$ of dark red crystals.

Preparation of Cryptocapsin-5,8-epoxides: To a solution of $3 \mathrm{mg}$ of semisynthetic cryptocapsin 5,6-epoxide (mixture of 5 and 7) in $50 \mathrm{~mL}$ of $\mathrm{Et}_{2} \mathrm{O}, 0.1 \mathrm{~mL}$ of $\mathrm{HOAc}-\mathrm{HCl}(9: 1)$ solution were added at room temperature. The mixture was kept under $\mathrm{N}_{2}$ in the dark. The reaction was monitored by UV-VIS. After $0.5 \mathrm{~h}$, the mixture was diluted with $\mathrm{Et}_{2} \mathrm{O}$, and washed with $5 \%$ aqueous $\mathrm{NaHCO}_{3}$ solution, the $\mathrm{Et}_{2} \mathrm{O}$ phase was dried over $\mathrm{Na}_{2} \mathrm{SO}_{4}$, and evaporated to dryness. The residue was crystallized from benzene and $n$-hexane (ratio 1:10), yielding $2.5 \mathrm{mg}$ of yellow crystals.

$\left(5 R, 6 S, 3^{\prime} S, 5^{\prime} R\right)$-Cryptocapsin-5,6-epoxide $\quad\left(\left(5 R, 6 S, 3^{\prime} S, 5^{\prime} R\right)-3^{\prime}\right.$-hydroxy-5,6-dihydro5,6-epoxy- $\boldsymbol{\beta}, \boldsymbol{\kappa}$-caroten-6'-one, 5): red crystals, mp. $136-137^{\circ} \mathrm{C}$, UV-VIS (benzene): $\lambda_{\max } 480$ 
and 505 (shoulder) nm, $\lambda_{\max }$ after acid treatment: 464, $486 \mathrm{~nm} ;{ }^{1} \mathrm{H} \mathrm{NMR}\left(400 \mathrm{MHz}, \mathrm{CDCl}_{3}\right) \delta$ 0.84 (3H, s Me-16'); 0.94 (3H, s Me-16); 1.04 (1H, dd, $\left.\mathrm{H}_{\mathrm{ax}}-2\right) ; 1.10$ (3H, s, Me-17), 1.15 (3H, s Me-18); 1.21 (3H, s Me-17'); 1.37 (3H, s, Me-18'); 1.43 (1H, m, H-3); 1.49 (1H, dd, $\mathrm{H}_{\mathrm{ax}}-4^{\prime}$, $\left.J_{\text {gem }}=14.5 \mathrm{~Hz}, J_{4^{\prime} \mathrm{ax}, 3^{\prime}}=3.1 \mathrm{~Hz}\right) ; 1.50\left(1 \mathrm{H}, \mathrm{dd}, \mathrm{H}_{\mathrm{eq}}-2\right) ; 1.71\left(1 \mathrm{H}, \mathrm{dd}, \mathrm{H}_{\mathrm{ax}}-2^{\prime}, J_{\mathrm{gem}}=13.7 \mathrm{~Hz}\right.$, $\left.\mathrm{J}_{2^{\prime} \mathrm{ax}, 3^{\prime}}=3.2 \mathrm{~Hz}\right) ; 1.72\left(1 \mathrm{H}, \mathrm{dd}, \mathrm{H}_{\mathrm{ax}}-4\right) ; 1.89\left(1 \mathrm{H}, \mathrm{dd}, \mathrm{H}_{\mathrm{eq}}-4\right) ; 1.94(3 \mathrm{H}, \mathrm{s}, \mathrm{Me}-19) ; 1.96$ (6H, s Me-20,19'); $1.98\left(3 \mathrm{H}, \mathrm{s}, \mathrm{Me}-20^{\prime}\right) ; 2.00\left(1 \mathrm{H}, \mathrm{dd}, \mathrm{H}_{\mathrm{eq}}-2^{\prime}, J_{\text {gem }}=13.7 \mathrm{~Hz}, J_{2^{\prime} \mathrm{eq}, 3^{\prime}}=7.8 \mathrm{~Hz}\right) ; 2.95$

$\left(1 \mathrm{H}, \mathrm{dd}, \mathrm{H}_{\mathrm{eq}}-4^{\prime}, J_{\text {gem }}=14.5 \mathrm{~Hz}, J_{4^{\prime} \mathrm{eq}, 3^{\prime}}=8.7 \mathrm{~Hz}\right) ; 4.51\left(1 \mathrm{H}, \mathrm{m}, \mathrm{H}-3^{\prime}\right) ; 5.90\left(1 \mathrm{H}, \mathrm{d}, \mathrm{H}-7, J_{7,8}=\right.$ $15.4 \mathrm{~Hz}) ; 6.19\left(1 \mathrm{H}, \mathrm{d}, \mathrm{H}-10, J_{10,11}=11.3 \mathrm{~Hz}\right) ; 6.27(1 \mathrm{H}, \mathrm{d}, \mathrm{H}-14) ; 6.29\left(1 \mathrm{H}, \mathrm{d}, J_{8,7}=15.4 \mathrm{~Hz}\right)$; $6.34\left(2 \mathrm{H}, \mathrm{m}, \mathrm{H}-8, \mathrm{H}-14^{\prime}\right) ; 6.37\left(1 \mathrm{H}, \mathrm{d}, \mathrm{H}-12, J_{12,11}=14.9 \mathrm{~Hz}\right) ; 6.44\left(1 \mathrm{H}, \mathrm{d}, \mathrm{H}-7^{\prime}, J_{7^{\prime}, 8^{\prime}}=15.1\right.$ $\mathrm{Hz}) ; 6.51\left(1 \mathrm{H}, \mathrm{dd}, \mathrm{H}-12^{\prime}, J_{12^{\prime}, 11^{\prime}}=14.6 \mathrm{~Hz}\right) ; 6.56\left(1 \mathrm{H}, \mathrm{d}, \mathrm{H}-10^{\prime}, J_{10^{\prime}, 11^{\prime}}=11.4 \mathrm{~Hz}\right) ; 6.61(1 \mathrm{H}, \mathrm{d}$, $\left.\mathrm{H}-11^{\prime}, J_{11^{\prime}, 10^{\prime}}=11.4 \mathrm{~Hz}\right) ; 6.63\left(1 \mathrm{H}, \mathrm{d}, \mathrm{H}-11, J_{11,10}=11.3 \mathrm{~Hz}\right) ; 6.65(1 \mathrm{H}, \mathrm{m}, \mathrm{H}-15) ; 6.69(1 \mathrm{H}, \mathrm{m}$, H-15'); $7.32\left(1 \mathrm{H}, \mathrm{d}, \mathrm{H}-8^{\prime}, J_{8^{\prime}, 7^{\prime}}=15.1 \mathrm{~Hz}\right) ;$ ECD $\{n$-hexane, $\lambda[\mathrm{nm}](\Delta \varepsilon)\}: 375(-0.46), 349$ (3.45), 334sh (2.59), 321sh (1.10), 281 (-8.05), 271sh (-4.47), 242 (3.53), 226sh (-1.42), 215 (-5.88); HRESITOFMS: $m / z$ 584.4240 (calcd. for $\mathrm{C}_{40} \mathrm{H}_{56} \mathrm{O}_{3}, 584.4229$ ).

\section{Mixture of $\left(5 R, 6 S, 3^{\prime} S, 5^{\prime} R\right)$-Cryptocapsin-5,6-epoxide (5) and $\left(5 S, 6 R, 3^{\prime} S, 5^{\prime} R\right)$ -}

Cryptocapsin-5,6-epoxide (7): red crystals, UV-VIS (benzene): $\lambda_{\max } 480$ and 505 (shoulder) $\mathrm{nm}, \lambda_{\max }$ after acid treatment: $464,486 \mathrm{~nm} ;{ }^{1} \mathrm{H}$ NMR $\left(400 \mathrm{MHz}, \mathrm{CDCl}_{3}\right): \delta 0.84(3 \mathrm{H}, \mathrm{s}, \mathrm{Me}-$ $\left.16^{\prime}\right) ; 0.94$ (3H, s, Me-17); 1.04 (1H, dd, $\left.\mathrm{H}_{\mathrm{ax}}-2\right) ; 1.10$ (3H, s, Me-16); 1.15 (3H, s, Me-18); 1.21 $\left(3 \mathrm{H}, \mathrm{s}, \mathrm{Me}-17^{\prime}\right) ; 1.37\left(3 \mathrm{H}, \mathrm{s}, \mathrm{Me}-18^{\prime}\right) ; 1.43(1 \mathrm{H}, \mathrm{m}, \mathrm{H}-3) ; 1.49\left(1 \mathrm{H}, \mathrm{dd}, \mathrm{H}_{\mathrm{ax}}-4^{\prime}, J_{\mathrm{gem}}=14.5 \mathrm{~Hz}\right.$, $\left.\mathrm{J}_{4^{\prime} \mathrm{ax}, 3^{\prime}}=3.1 \mathrm{~Hz}\right) 1.50\left(1 \mathrm{H}, \mathrm{dd}, \mathrm{H}_{\mathrm{eq}}-2\right) ; 1.70\left(1 \mathrm{H}, \mathrm{dd}, \mathrm{H}_{\mathrm{ax}}-2^{\prime}, J_{\mathrm{gem}}=13.7 \mathrm{~Hz}, J_{2^{\prime} \mathrm{ax}, 3^{\prime}}=3.2 \mathrm{~Hz}\right) ; 1.72$ (1H, dd, $\left.\mathrm{H}_{\mathrm{ax}}-4\right) ; 1.89$ (1H, dd, $\left.\mathrm{H}_{\mathrm{eq}}-4\right) ; 1.94$ (3H, s, Me-19); 1.96 (3H, s, Me-19'); 1.98 (6H, s, Me-20, 20'); $2.00\left(1 \mathrm{H}, \mathrm{dd}, \mathrm{H}_{\mathrm{eq}}-2^{\prime}, J_{\text {gem }}=13.7 \mathrm{~Hz}, \mathrm{~J}_{2^{\prime} \mathrm{eq}, 3^{\prime}}=7.8 \mathrm{~Hz}\right) ; 2.95\left(1 \mathrm{H}, \mathrm{dd}, \mathrm{H}_{\mathrm{eq}}-4^{\prime}, J_{\text {gem }}=\right.$ $\left.14.5 \mathrm{~Hz}, \mathrm{~J}_{4^{\prime} \mathrm{eq}, 3^{\prime}}=8.7 \mathrm{~Hz}\right)$; $4.51\left(1 \mathrm{H}, \mathrm{m}, \mathrm{H}-3^{\prime}\right) ; 5.90\left(1 \mathrm{H}, \mathrm{d}, \mathrm{H}-7, J_{7,8}=15.4 \mathrm{~Hz}\right), 6.19(1 \mathrm{H}, \mathrm{d}, \mathrm{H}-$ $\left.10, J_{10,11}=11.3 \mathrm{~Hz}\right) ; 6.27(1 \mathrm{H}, \mathrm{d}, \mathrm{H}-14) ; 6.29\left(1 \mathrm{H}, \mathrm{d}, \mathrm{H}-8, J_{8,7}=15.4 \mathrm{~Hz}\right) ; 6.34\left(1 \mathrm{H}, \mathrm{d}, \mathrm{H}-14^{\prime}\right)$; $6.37\left(1 \mathrm{H}, \mathrm{d}, \mathrm{H}-12, J_{12,11}=14.9 \mathrm{~Hz}\right) ; 6.44\left(1 \mathrm{H}, \mathrm{d}, \mathrm{H}^{-} 7^{\prime}, J_{7^{\prime}, 8^{\prime}}=15.1 \mathrm{~Hz}\right) ; 6.51\left(1 \mathrm{H}, \mathrm{d}, \mathrm{H}-12^{\prime}\right.$, $\left.J_{12^{\prime}, 11^{\prime}}=14.6 \mathrm{~Hz}\right), 6.56\left(1 \mathrm{H}, \mathrm{d}, \mathrm{H}-10^{\prime}, J_{10^{\prime}, 11^{\prime}}=11.4 \mathrm{~Hz}\right) ; 6.61\left(1 \mathrm{H}, \mathrm{dd}, \mathrm{H}-11^{\prime}, J_{11^{\prime}, 10^{\prime}}=11.4 \mathrm{~Hz}\right)$; $6.63(1 \mathrm{H}, \mathrm{d}, \mathrm{H}-11) ; 6.65(1 \mathrm{H}, \mathrm{m}, \mathrm{H}-15) ; 6.69\left(1 \mathrm{H}, \mathrm{m}, \mathrm{H}-15^{\prime}\right) ; 7.32\left(1 \mathrm{H}, \mathrm{d}, \mathrm{H}-8^{\prime}, J_{7^{\prime}, 8^{\prime}}=15.1\right.$ $\mathrm{Hz}) ;{ }^{13} \mathrm{C} \mathrm{NMR}\left(100 \mathrm{MHz}, \mathrm{CDCl}_{3}\right)$ : $\delta 12.7$ (C-20); 12.8 (C-20',19); 13.0 (C-19'); 17.10 (C-3); 21.1 (C-18); 21.3 (C-18'); 25.1 (C-17'); 25.9 (C-16',17); 26.0 (C-16); 30.1 (C-4); 33.83 (C-1); 35.8 (C-2); 44.0 (C-1'); 45.3 (C-4'); 50.9 (C-2'); 58.93 (C-5'); 65.5 (C-5); 70.4 (C-3'); 71.4 (C6); 120.90 (C-7'); 124.1 (C-11'); 124.4 (C-7); 125.33 (C-11); 129.8 (C-15); 131.6 (C-15'); 131. 8 (C-10); 132.5 (C-14); 133.6 (C-9'); 134.9 (C-9); 135.2 (C-14'); 136.0 (C-13); 137.2 (C- 
8); 137.5 (C-13'); 137.8 (C-12); 140.7 (C-10'); 141.9 (C-12'); 146.8 (C-8'); 202.9 (C-6'); HRESITOFMS: $m / z 584.4246$ (calcd. for $\mathrm{C}_{40} \mathrm{H}_{56} \mathrm{O}_{3}, 584.4229$ ); 5: $\mathrm{tr}=31.0 \mathrm{~min} ; \mathrm{7}: \operatorname{tr}=43.1$ min on Chiralcel OD column $(0.46 \mathrm{~cm} \times 25 \mathrm{~cm}, 5 \mu \mathrm{m})$ with $n$-hexane/EtOH 1:1 and a flow rate $0.5 \mathrm{~mL} / \mathrm{min}$.

7: HPLC-ECD $\{n$-hexane/EtOH 1:1, $\lambda[\mathrm{nm}](\phi)\}: 351(-0.91), 321 \mathrm{sh}(-0.34), 282$ (3.89), 268sh (1.81), 251sh (0.63), 231 (2.16), 208 (-24.98).

5: HPLC-ECD $\{n$-hexane/EtOH 1:1, $\lambda[\mathrm{nm}](\phi)\}: 385(-0.15), 353$ (1.06), 339sh (0.96), 324sh (0.47), 283 (-2.96), 271sh (-1.65), 242 (1.09), 215 (-2.45).

\section{3'-Deoxycapsanthin-5,6-epoxide $\quad\left(\left(3 S, 5 S, 6 R, 5^{\prime} R\right)-3\right.$-hydroxy-5,6-dihydro-5,6-epoxy-}

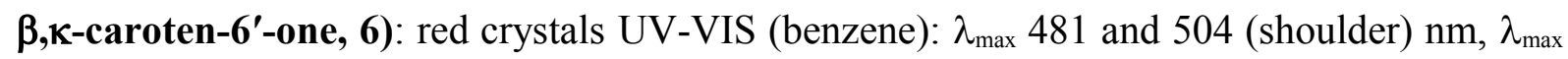
after acid treatment: 463, $485 \mathrm{~nm} ;{ }^{1} \mathrm{H}$ NMR (500 MHz, $\left.\mathrm{CDCl}_{3}\right): \delta 0.85\left(3 \mathrm{H}, \mathrm{s}, \mathrm{Me}-16{ }^{\prime}\right) ; 0.98$ (3H, s, Me-17); 1.11 (3H, s, Me-17'); 1.16 (3H, s, Me-16); 1.19 (3H, s, Me-18); 1.27 (1H, dd, $\left.\mathrm{H}_{\mathrm{ax}}-2, J_{2 \mathrm{ax}, 3}=10.2 \mathrm{~Hz}\right), 1.30\left(3 \mathrm{H}, \mathrm{s} \mathrm{Me}-18^{\prime}\right) ; 1.50\left(1 \mathrm{H}, \mathrm{dd}, \mathrm{H}_{\mathrm{ax}}-4^{\prime}\right), 1.57\left(1 \mathrm{H}, \mathrm{dd}, \mathrm{H}_{\mathrm{eq}}-2^{\prime}\right) ; 1.62$ $\left(1 \mathrm{H}, \mathrm{ddd}, \mathrm{H}_{\mathrm{eq}}-2, J_{\mathrm{gem}}=14.7 \mathrm{~Hz}, J_{2 \mathrm{eq} .3}=3.6 \mathrm{~Hz}, J_{2 \mathrm{eq} .4}=1.7 \mathrm{~Hz}\right), 1.65\left(1 \mathrm{H}, \mathrm{dd}, \mathrm{H}_{\mathrm{ax}}-4, J_{\mathrm{gem}}=14.2\right.$ $\left.\mathrm{Hz}, J_{4 a x .3}=8.8 \mathrm{~Hz}\right) ; 1.68\left(1 \mathrm{H}, \mathrm{dd}, \mathrm{H}_{\mathrm{ax}}-2^{\prime}\right) ; 1.70\left(1 \mathrm{H}, \mathrm{m}, \mathrm{H}-3^{\prime}\right) ; 1.93(1 \mathrm{H}, \mathrm{s}, \mathrm{Me}-19) ; 1.97(3 \mathrm{H}$, s, Me-19'), $1.98\left(6 \mathrm{H}, \mathrm{s}, \mathrm{Me}-20,20^{\prime}\right) ; 2.36\left(1 \mathrm{H}, \mathrm{dd}, \mathrm{H}_{\mathrm{eq}}-4\right) ; 2.55\left(1 \mathrm{H}, \mathrm{dd}, \mathrm{H}_{\mathrm{eq}}-4^{\prime}\right) ; 3.93(1 \mathrm{H}, \mathrm{m}$, $\mathrm{H}-3), 5.92\left(1 \mathrm{H}, \mathrm{d}, \mathrm{H}-7, J_{7,8}=15.5 \mathrm{~Hz}\right) ; 6.20\left(1 \mathrm{H}, \mathrm{d}, \mathrm{H}-10, J_{10,11}=11.5 \mathrm{~Hz}\right) ; 6.26(1 \mathrm{H}, \mathrm{H}-14)$; $6.29\left(1 \mathrm{H}, \mathrm{d}, \mathrm{H}-8, J_{7,8}=15.5 \mathrm{~Hz}\right) ; 6.34\left(1 \mathrm{H}, \mathrm{d}, \mathrm{H}-14^{\prime}\right) ; 6.36\left(1 \mathrm{H}, \mathrm{d}, \mathrm{H}-12, J_{11,12}=13 \mathrm{~Hz}\right) ; 6.48$ $\left(1 \mathrm{H}, \mathrm{d}, \mathrm{H}-7^{\prime}, J_{7^{\prime}, 8^{\prime}}=15 \mathrm{~Hz}\right) ; 6.51\left(1 \mathrm{H}, \mathrm{d}, \mathrm{H}-12^{\prime}, J_{11^{\prime}, 12^{\prime}}=14.5 \mathrm{~Hz}\right) ; 6.57\left(1 \mathrm{H}, \mathrm{d}, \mathrm{H}-10^{\prime}, J_{10^{\prime}, 11^{\prime}}=\right.$ $11.3 \mathrm{~Hz}) ; 6.59$ (1H, dd, H-11); 6.63 (1H, dd, H-11'); 6.64 (1H, m, H-15); 6.67 (1H, m, H-15'); $7.32\left(1 \mathrm{H}, \mathrm{d}, \mathrm{H}-\mathrm{C} 8^{\prime}, J_{7^{\prime}, 8^{\prime}}=15 \mathrm{~Hz}\right)$; ECD $\{n$-hexane, $\lambda[\mathrm{nm}](\Delta \varepsilon)\}: 365(-0.14), 347(2.32)$, 332sh (1.69), 315sh (0.48), 280 (-6.35), 270sh (-3.64), 240 (2.52), 233sh (0.78), 214 (-4.10). HR ESI-TOF MS: $m / z 584.4231$ (calcd. for $\mathrm{C}_{40} \mathrm{H}_{56} \mathrm{O}_{3}, 584.4229$ ).

$\left(3 S, 5 R, 6 S, 5^{\prime} R, 6^{\prime} S\right)-\beta-C r y p t o x a n t h i n-5,6,5^{\prime}, 6^{\prime}$-diepoxide $\left(\left(3 S, 5 R, 6 S, 5^{\prime} R, 6^{\prime} S\right)-3-\right.$ hydroxy-5,6,5', $6^{\prime}$-tetrahydro-5,6,5', $6^{\prime}$-diepoxy- $\beta, \beta$-caroten-3-ol, 8) orange crystals, mp. 148-150 ${ }^{\circ} \mathrm{C}$, UV-VIS (benzene): $\lambda_{\max } 428,453$, and $483 \mathrm{~nm}, \lambda_{\max }$ after acid treatment: 388 , 410, $436 \mathrm{~nm} ;{ }^{1} \mathrm{H}$ NMR (500 MHz, $\mathrm{CDCl}_{3}$ ): $\delta 0.95$ (3H, s, Me-16'); 0.98 (3H, s, Me-16); 1.08 $\left(1 \mathrm{H}, \mathrm{m}, \mathrm{H}-2^{\prime}\right) ; 1.11$ (3H, s, Me-17'); 1.15 (3H, s, Me-17); 1.16 (3H, s, Me-18'); 1.19 (3H, s, Me-18); 1.42 (1H, m, H-3'); 1.47 (1H, m, H-2'); 1.75 (1H, m, H-4'); 1.90 (1H, m, H-4'); 1.94 $\left(6 \mathrm{H}, \mathrm{s}, \mathrm{Me}-19,19^{\prime}\right) ; 1.97$ (6H, s, Me-20,20'); $1.26\left(1 \mathrm{H}, \mathrm{m}, \mathrm{H}-2_{\mathrm{ax}}\right) ; 1.57$ (1H, m, H-2 $)$; 1.64 $\left(1 \mathrm{H}, \mathrm{m}, \mathrm{H}-4_{\mathrm{ax}}\right) ; 2.40\left(1 \mathrm{H}, \mathrm{m}, \mathrm{H}-4_{\mathrm{eq}}\right) ; 3.92\left(1 \mathrm{H}, \mathrm{m}, \mathrm{H}-3_{\mathrm{ax}}\right) ; 5.88\left(1 \mathrm{H}, \mathrm{d}, \mathrm{H}-7, J_{7,8}=15.4 \mathrm{~Hz}\right)$, 
$6.20\left(2 \mathrm{H}, \mathrm{d}, \mathrm{H}-10,10^{\prime}\right) ; 6.27$ (1H, d, H-8); 6.29 (2H, d, H-14,14'); 6.36 (2H, d, H-12,12', J12,11 $=15 \mathrm{~Hz}) ; 6.60\left(2 \mathrm{H}, \mathrm{d}, \mathrm{H}-11,11^{\prime}, J_{11,10}=11 \mathrm{~Hz}\right), 6.63\left(2 \mathrm{H}, \mathrm{dd}, \mathrm{H}-15,15^{\prime}\right)$; ECD \{ $n$-hexane, $\lambda$ [nm] $(\Delta \varepsilon)\}: 355$ (0.17), 327 (1.57), 312sh (0.81), 266 (-10.04), 255sh (-4.72), 230 (2.72), 208 (-5.05); HR ESI-TOF MS: $m / z 584.4214$ (calcd. for $\mathrm{C}_{40} \mathrm{H}_{56} \mathrm{O}_{3}, 584.4229$ ).

Mixture of $\left(5 R, 8 S, 3 S, 5^{\prime} R\right)$-Cryptocapsin-5,8-epoxide (11) and $\left(5 R, 8 R, 3^{\prime} S, 5^{\prime} R\right)$ Cryptocapsin-5,8-epoxide (12): orange crystals, UV-VIS (benzene): $\lambda_{\max } 464,486 \mathrm{~nm}$; HRESITOFMS: $m / z 584.4301$ (calcd. for $\mathrm{C}_{40} \mathrm{H}_{56} \mathrm{O}_{3}, 584.4229$ ). $\mathrm{t}_{\mathrm{r}}=14.3 \mathrm{~min}$ for 11 and 19.0 $\min$ for 12 on Chiralcel IC $(5 \mu \mathrm{m}, 150 \times 4.6 \mathrm{~mm})$ with n-hexane/EtOH 8:2 and a flow rate of $1.0 \mathrm{~mL} / \mathrm{min}$.

$\left(5 R, 8 S, 3^{\prime} S, 5^{\prime} R\right)$-Cryptocapsin-5,8-epoxide $\quad\left(\left(5 R, 8 S, 3^{\prime} S, 5^{\prime} R\right)-3^{\prime}\right.$-hydroxy-5,6-dihydro-

\section{5,8-epoxy- $\beta, \kappa$-caroten- 6 '-one, 11)}

${ }^{1} \mathrm{H}$ NMR $\left(500 \mathrm{MHz}, \mathrm{CDCl}_{3}\right) \delta 0.84\left(3 \mathrm{H}, \mathrm{s}, \mathrm{Me}-16\right.$ '), $1.12(3 \mathrm{H}, \mathrm{s} \mathrm{Me}-16)^{\mathrm{b}}, 1.19(3 \mathrm{H}, \mathrm{s}, \mathrm{Me}-$ 17) $)^{\mathrm{b}}, 1.22$ (3H, s Me-17'), 1.38 (3H, s Me-18'), 1.48 (3H, s Me-18), 1.49 (1H, dd, $\mathrm{H}_{\mathrm{ax}}-\mathrm{C} 4^{\prime}$, $\left.J_{\text {gem }}=14.5 \mathrm{~Hz}, \mathrm{~J}_{4^{\prime} \mathrm{ax}, 3^{\prime}}=3.1 \mathrm{~Hz}\right), 1.71\left(1 \mathrm{H}, \mathrm{dd}, \mathrm{H}_{\mathrm{ax}}-2^{\prime}, J_{\mathrm{gem}}=13.7 \mathrm{~Hz}, \mathrm{~J}_{2^{\prime} \mathrm{ax}, 3^{\prime}}=3.2 \mathrm{~Hz}\right), 1.81(3 \mathrm{H}, \mathrm{s}$, Me-19); 1.96 (3H, s, Me-19'); 1.98 (6H, s, Me-20,20'); $2.02\left(1 \mathrm{H}, \mathrm{dd}, \mathrm{H}_{\mathrm{eq}}-2^{\prime}, J_{\mathrm{gem}}=13.7 \mathrm{~Hz}\right.$, $\left.J_{2^{\prime} \text { eq, }, 3^{\prime}}=7.8 \mathrm{~Hz}\right) ; 2.95\left(1 \mathrm{H}, \mathrm{dd}, \mathrm{H}_{\mathrm{eq}}-4^{\prime}, J_{\text {gem }}=14.5 \mathrm{~Hz}, J_{4^{\prime} \mathrm{eq}, 3^{\prime}}=8.7 \mathrm{~Hz}\right) ; 4.51\left(1 \mathrm{H}, \mathrm{m}, \mathrm{H}-3^{\prime}\right) ; 5.07$ $\left(1 \mathrm{H}\right.$, br. s, H-8, $\left.\mathrm{J}_{7,8} \sim 1.7 \mathrm{~Hz}\right) ; 5.24(1 \mathrm{H}, \mathrm{d}, \mathrm{H}-7) ; 6.19\left(1 \mathrm{H}, \mathrm{d}, \mathrm{H}-10, J_{10,11}=11.2 \mathrm{~Hz}\right), 6.23(1 \mathrm{H}$, d, H-14, $\left.J_{14,15}=11.4 \mathrm{~Hz}\right) ; 6.32(1 \mathrm{H}, \mathrm{d}, \mathrm{H}-12) ; 6.34\left(1 \mathrm{H}, \mathrm{d}, \mathrm{H}-14^{\prime}\right) ; 6.46\left(1 \mathrm{H}, \mathrm{d}, \mathrm{H}-7^{\prime}, J_{7^{\prime}, 8^{\prime}}=\right.$ $15.1 \mathrm{~Hz}), 6.51\left(1 \mathrm{H}, \mathrm{dd}, \mathrm{H}-11, J_{11,10}=15.0 \mathrm{~Hz}\right) ; 6.53\left(1 \mathrm{H}, \mathrm{d}, \mathrm{H}-12^{\prime}, J_{12^{\prime}, 11^{\prime}}=14.6 \mathrm{~Hz}\right), 6.57(1 \mathrm{H}$, d, H-10', $\left.J_{10^{\prime}, 11^{\prime}}=11.2 \mathrm{~Hz}\right) ; 6.62\left(1 \mathrm{H}, \mathrm{dd}, \mathrm{H}-11^{\prime}\right) ; 6.64(1 \mathrm{H}, \mathrm{m}, \mathrm{H}-15) ; 6.70\left(1 \mathrm{H}, \mathrm{m}, \mathrm{H}-15^{\prime}\right)$; $7.32\left(1 \mathrm{H}, \mathrm{d}, \mathrm{H}-8^{\prime}, J_{8^{\prime}, 7^{\prime}}=15.1 \mathrm{~Hz}\right) ;{ }^{13} \mathrm{C} \mathrm{NMR}\left(125 \mathrm{MHz}, \mathrm{CDCl}_{3}\right): \delta 12.5(\mathrm{C}-19) ; 12.9(\mathrm{C}-$ $\left.20^{\prime}\right)^{\text {a }} ; 13.0\left(\mathrm{C}-19^{\prime}, 20\right)^{\text {b }} ; 20.3$ (C-3); 21.3 (C-18'); 25.1 (C-17'); 25.8 (C-16); 25.9 (C-16'); 25.9 (C-18); 30.6 (C-17); 41.2 (C-4); 41.4 (C-2); 45.3 (C-4'); 50.9 (C-2'); 70.4 (C-3'); 87.7 (C-8); 117.6 (C-7); 120.9 (C-7'), 124.2 (C-11'), 126.8 (C-10); 131.7 (C-15'), 134.9 (C-14'), 140.7 (C10'), $141.9\left(\mathrm{C}-12^{\prime}\right), 146.8\left(\mathrm{C} 8^{\prime}\right)$. HPLC-ECD $\{n$-hexane/EtOH 8:2, $\lambda[\mathrm{nm}](\phi)\}: 376(-0.87)$, 330 (2.82), 321sh (2.63), 282sh (-0.68), 267 (-3.73), 229sh (-2.55), 204 (-12.22).

$\left(5 R, 8 R, 3^{\prime} S, 5^{\prime} R\right)$-Cryptocapsin-5,8-epoxide $\quad\left(\left(5 R, 8 R, 3^{\prime} S, 5^{\prime} R\right)-3^{\prime}\right.$-hydroxy-5,6-dihydro5,8-epoxy- $\beta$, к-caroten-6'-one, 12) 
${ }^{1} \mathrm{H}$ NMR $\left(500 \mathrm{MHz}, \mathrm{CDCl}_{3}\right) \delta 0.84\left(3 \mathrm{H}, \mathrm{s}, \mathrm{Me}-16\right.$ '), $1.11(3 \mathrm{H}, \mathrm{s}, \mathrm{Me}-16){ }^{\mathrm{a}}, 1.16(3 \mathrm{H}, \mathrm{s}, \mathrm{Me}-$ 17) $)^{\mathrm{a}}, 1.22\left(3 \mathrm{H}, \mathrm{s}, \mathrm{Me}-17^{\prime}\right) ; 1.25$ (1H, m, $\left.\mathrm{H}_{\mathrm{ax}}-2\right)$; 1.38 (3H, s, Me-18'), 1.44 (3H, s, Me-18), $1.49\left(1 \mathrm{H}, \mathrm{dd}, \mathrm{H}_{\mathrm{ax}}-4^{\prime}, J_{\mathrm{gem}}=14.5 \mathrm{~Hz}, J_{4^{\prime} \mathrm{ax}, 3^{\prime}}=3.1 \mathrm{~Hz}\right), 1.59\left(1 \mathrm{H}, \mathrm{m}, \mathrm{H}_{\mathrm{eq}}-2\right) ; 1.61\left(1 \mathrm{H}, \mathrm{m}, \mathrm{H}_{\mathrm{ax}}-4\right)$; $1.65(1 \mathrm{H}, \mathrm{m}, \mathrm{H}-3) ; 1.71\left(1 \mathrm{H}, \mathrm{dd}, \mathrm{H}_{\mathrm{ax}}-2^{\prime}, J_{\mathrm{gem}}=13.6 \mathrm{~Hz}\right) ; 1.76(3 \mathrm{H}, \mathrm{s}, \mathrm{Me}-19) ; 1.96(3 \mathrm{H}, \mathrm{s}, \mathrm{Me}-$ $\left.19^{\prime}\right) ; 1.98\left(6 \mathrm{H}, \mathrm{s}, \mathrm{Me}-20,20^{\prime}\right) ; 2.01\left(1 \mathrm{H}, \mathrm{m}, \mathrm{H}_{\mathrm{eq}}-4\right) ; 2.02\left(1 \mathrm{H}, \mathrm{dd}, \mathrm{H}_{\mathrm{eq}}-2^{\prime}, J_{2^{\prime} \mathrm{eq}, 3^{\prime}}=8.1 \mathrm{~Hz}\right) ; 2.95$ $\left(1 \mathrm{H}, \mathrm{dd}, \mathrm{H}_{\mathrm{eq}}-4^{\prime}, J_{4^{\prime} \mathrm{eq}, 3^{\prime}}=8.5 \mathrm{~Hz}\right) ; 4.51\left(1 \mathrm{H}, \mathrm{m}, \mathrm{H}-3^{\prime}\right) ; 5.16\left(1 \mathrm{H}, \mathrm{d}, \mathrm{H}-7, J_{7,8}<1 \mathrm{~Hz}\right) ; 5.18(1 \mathrm{H}, \mathrm{d}$, H-8); $6.20\left(1 \mathrm{H}, \mathrm{d}, \mathrm{H}-10, J_{10,11}=11.4 \mathrm{~Hz}\right) ; 6.23\left(1 \mathrm{H}, \mathrm{d}, \mathrm{H}-14, J_{14,15}=11.4 \mathrm{~Hz}\right) ; 6.32(1 \mathrm{H}, \mathrm{d}, \mathrm{H}-$ $\left.12, J_{12,11}=15 \mathrm{~Hz}\right), 6.34\left(1 \mathrm{H}, \mathrm{d}, \mathrm{H}-14^{\prime}\right) ; 6.46\left(1 \mathrm{H}, \mathrm{d}, \mathrm{H}^{\prime} 7^{\prime}, J_{7^{\prime}, 8^{\prime}}=15.1 \mathrm{~Hz}\right) ; 6.51(1 \mathrm{H}, \mathrm{dd}, \mathrm{H}-11$, $\left.J_{11,10}=15.0 \mathrm{~Hz}\right) ; 6.53\left(1 \mathrm{H}, \mathrm{dd}, \mathrm{H}-12^{\prime}, J_{12^{\prime}, 11^{\prime}}=14.6 \mathrm{~Hz}\right) ; 6.57\left(1 \mathrm{H}, \mathrm{d}, \mathrm{H}-10^{\prime}, J_{10^{\prime}, 11^{\prime}}=11.4 \mathrm{~Hz}\right)$; $6.62\left(1 \mathrm{H}, \mathrm{dd}, \mathrm{H}-11^{\prime}\right) ; 6.64$ (1H, m, H-15); 6.70 (1H, m, H-15'); $7.32\left(1 \mathrm{H}, \mathrm{d}, \mathrm{H}-8^{\prime}, J_{8^{\prime} 7^{\prime}}=15.1\right.$ $\mathrm{Hz}) ;{ }^{13} \mathrm{C} \mathrm{NMR}\left(125 \mathrm{MHz}, \mathrm{CDCl}_{3}\right): \delta 12.5(\mathrm{C}-19) ; 12.9\left(\mathrm{C}-20^{\prime}\right)^{\mathrm{a}} ; 13.0\left(\mathrm{C}-19^{\prime}, 20\right)^{\mathrm{b}} ; 20.3(\mathrm{C}-$ 3); 21.3 (C-18'); 25.1 (C-17'); 25.8 (C-16); 25.9 (C-16'); 25.9 (C-18); 30.6 (C-17); 41.2 (C-4); 41.4 (C-2); 45.3 (C-4'); 50.9 (C-2'); 70.4 (C-3'); 87.1 (C-8); 118.7 (C-7); 120.9 (C-7'); 124.2 (C-11'); 126.8 (C-10); 131.6 (C-15'); 134.9 (C-14'); 140.7 (C-10'); 141.9 (C-12'); 146.8 (C$\left.8^{\prime}\right)$. HPLC-ECD $\{n$-hexane/EtOH 8:2, $\lambda[\mathrm{nm}](\phi)\}: 395$ (-0.13), 373sh (-0.68), $348(-1.29)$, 265 (7.73), 234sh (3.14), 205 (18.85).

$\left(5 S, 8 R, 3^{\prime} S, 5^{\prime} R\right)$-Cryptocapsin-5,8-epoxide $\quad\left(\left(5 S, 8 R, 3^{\prime} S, 5^{\prime} R\right)-3^{\prime}\right.$-hydroxy-5,6-dihydro-

\section{5,8-epoxy- $\beta, \kappa$-caroten-6'-one, 13 )}

$\mathrm{t}_{\mathrm{r}}=15.8 \mathrm{~min}$ on Chiralcel IC $(5 \mu \mathrm{m}, 150 \times 4.6 \mathrm{~mm})$ with $n$-hexane/EtOH 8:2 and a flow rate of $1.0 \mathrm{~mL} / \mathrm{min}$. HPLC-ECD $\{n$-hexane/EtOH 8:2, $\lambda[\mathrm{nm}](\phi)\}: 391(0.21), 367 \mathrm{sh}(-0.30), 354$ (-0.41), 325 (0.61), 265sh (2.36), 258 (2.37), 234sh (1.79), 205 (7.98).

$\left(5 S, 8 S, 3^{\prime} S, 5^{\prime} R\right)$-Cryptocapsin-5,8-epoxide $\quad\left(\left(5 S, 8 S, 3^{\prime} S, 5^{\prime} R\right)-3^{\prime}\right.$-hydroxy-5,6-dihydro5,8-epoxy- $\beta, \kappa$-caroten-6'-one, 14$)$

$\mathrm{t}_{\mathrm{r}}=17.2 \mathrm{~min}$ on Chiralcel IC $(5 \mu \mathrm{m}, 150 \times 4.6 \mathrm{~mm})$ with $n$-hexane/EtOH 8:2 and a flow rate of $1.0 \mathrm{~mL} / \mathrm{min}$. HPLC-ECD $\{n$-hexane/EtOH 8:2, $\lambda[\mathrm{nm}](\phi)\}: 364(-0.85), 331$ (5.35), 321sh (4.78), 306sh (2.12), 284sh (-0.58), 267 (-7.54), 233sh (-2.24), 204 (-18.44). 


\section{ASSOCIATED CONTENT}

\section{Supporting Information}

1D and 2D NMR spectra for compounds 5-11. Supplementary data associated with this article are available free of charge via the Internet at http://pubs.acs.org.

\section{AUTHOR INFORMATION}

\section{Corresponding author}

Tel.: +36-72-536356; fax: +36-72-536225; e-mail:jozsef.deli@aok.pte.hu

\section{ACKNOWLEDGEMENTS}

This study was supported by the grants OTKA K 83898, K 105871, K 105459 (Hungarian National Research Foundation) and SENACYT (Secretaria Nacional de Ciencia y Tecnología de Panamá). The work is supported by the TÁMOP-4.2.2.A-11/1/KONV-2012-0025 and the TÁMOP/SROP-4.2.2/B-10/1-2010-0029 projects. The projects are co-financed by the European Union and the European Social Fund. The authors thank Ms. Zs. Götz, Mrs. J. Rigó and Mr. N. Götz for their skillful assistance.

\section{DEDICATION}

This article is dedicated to the memory of late Prof. Hans Conrad Eugster (17.07.1921 21.08.2012).

\section{REFERENCES}

(1) Zechmeister, L.; Cholnoky, L. Justus Liebigs. Ann. Chem. 1927, 454, $54-71$.

(2) Deli, J.; Molnár, P. Curr. Org. Chem. 2002, 6, 1197-1219.

(3) Deli, J.; Matus, Z.; Tóth, G. Z. Lebensm. Unters. Forsch. A 1997, 205, 388-391.

(4) Karrer, P.; Oswald, A. Helv. Chim. Acta 1935, 18, 1303-1305.

(5) Deli, J.; Molnár, P.; Matus, Z.; Tóth, G.; Steck, A.; Pfander, H. Chromatographia 1998, $48,27-31$.

(6) Bubicz, M. Bull. Acad. Polon. Sci. Ser. Sci. Biol. 1965, 13, 251-255.

(7) Simpson, D. J.; Baqar, M. R.; Lee, T. H. Ann. Bot. 1977, 41, 1101-1107.

(8) Deli, J.; Matus, Z.; Tóth, G. J. Agr. Food Chem. 2000, 48, 2793-2796.

(9) Seybold, . A. Sber. Heidelb. Akad. Wiss. Math.-Naturwiss. Kl. 1953, 4, 31-124. 
(10) Parkes, K. E. B.; Pattenden, G.; Baranyai, M.; Molnár, P.; Szabolcs, J.; Tóth, G. Tetrahedron Lett. 1986, 27, 2535-2538.

(11) Deli, J.; Molnár, P.; Matus, Z.; Tóth, G.; Steck, A. Helv. Chim. Acta 1996, 79, 14351443

(12) Deli, J.; Molnár, P.; Matus, Z.; Tóth, G.; Steck, A.; Pfander, H. Helv. Chim. Acta 1998, $81,1233-1241$.

(13) Deli, J.; Molnár, P.; Ösz, E.; Tóth, G. Tetrahedron Letters 2000, 41, 8153-8155.

(14) Maoka, T.; Akimoto, N.; Fujiwara, Y.; Hashimoto, K. J. Nat. Prod. 2004, 67, 115-117.

(15) Murillo, E.; Watts, M.; Mosquera, V.; Robinson, J.; McLean, R. Acta Biol. Cracov. 2011, 53 (Suppl. 1) 61.

(16) Murillo, E.; McLean, R.; Britton, G.; Agócs, A.; Nagy, V.; Deli, J. J. Nat. Prod. 2011, 74, 283-285.

(17) Murillo, E.; Mosquera, Y.; Kurtán, T.; Gulyás-Fekete, G.; Nagy, V.; Deli, J. Helv.

Chim. Acta 2012, 95, 983-988.

(18) Deli, J.; Turcsi, E.; Szabó, I.; Mosquera, Y.; Murillo, E. Acta Biol. Cracov. 2011, 53 (Suppl. 1) 55.

(19) Molnár, P.; Deli, J.; Matus, Z.; Tóth, G.; Steck, A.; Pfander, H. Helv. Chim. Acta 1997, 80, 221-229.

(20) Deli, J.; Molnár, P.; Matus, Z.; Tóth, G.; Steck, A.; Pfander, H. Helv. Chim. Acta 1998, $81,1242-1253$.

(21) Buchecker, R.; Noack, K. Circular Dichroism. In Carotenoids Vol. 1B. Spectroscopy, Britton, G. Liaaen-Jensen, S. Pfander, H. Eds. Birkhäuser: Basel, 1995; pp. 63-116.

(22) Dai, J.; Krohn, K.; Flörke, U.; Draeger, S.; Schulz, B.; Kiss-Szikszai, A.; Antus, S.;

Kurtán, T.; van Ree, T. Eur. J. Org. Chem. 2006, 3498-3506.

(23) Yao, S.; Tang, C.-P.; Ye, Y.; Kurtán, T.; Kiss-Szikszai, A.; Antus S.; Pescitelli, G.; Salvadori, P.; Krohn, K. Tetrahedron: Asymmetry 2008, 19, 2007-2014.

(24) Bringmann, G.; Götz, D.; Bruhn, T. in: Comprehensive Chiroptical Spectroscopy (Eds.: Berova, N.; Polavarapu, P. L.; Nakanishi, K.; Woody R. W.), John Wiley \& Sons, Hoboken, 2012, vol. 2, pp. 355-420.

(25) Englert, G. NMR Spectroscopy. In Carotenoids Vol. 1B. Spectroscopy, Eds. Britton, G.; Liaaen-Jensen,; S. Pfander, H. Birkhäuser Verlag, Basel, 1995, pp. 147 - 260.

(26) Acemoglu, M.; Prewo, R.J.; Bieri, H.; Eugster, C. H. Helv. Chim. Acta 1984, 67, 175183.

(27) Eugster, C. H. Pure Appl. Chem. 1985, 57, 639-647. 
(28) Eschenmoser, W.; Marki-Fischer, E.; Eugster, C. H. Helv. Chim. Acta 1984, 67, 170174.

(29) Bouvier, F.; Hugueney, P.; d'Harlingue, A.; Kuntz, M.; Camara, B. Plant J. 1994, 6, $45-54$. 


\section{Structures:}
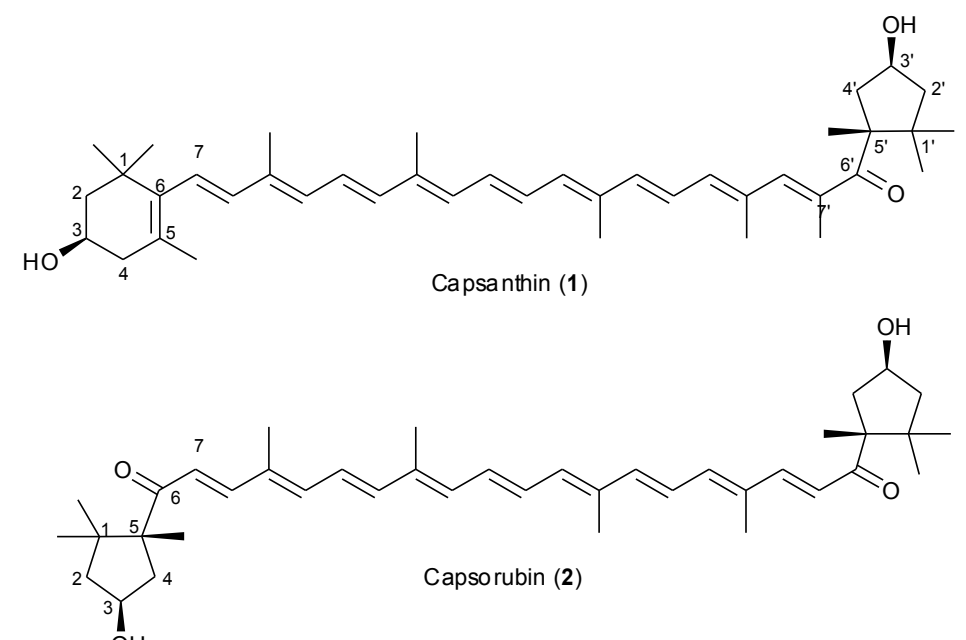<smiles>CC1=C(/C=C/C(C)=C/C=C/C(C)=C/C=C/C=C(C)/C=C/C=C(C)/C=C/C(=O)[C@@]2(C)CC(O)CC2(C)C)C(C)(C)CCC1</smiles><smiles>CC1=C(/C=C/C(C)=C/C=C/C(C)=C/C=C/C=C(C)/C=C/C=C(C)/C=C/C(=O)C2(C)CCCC2(C)C)C(C)(C)CCC1</smiles> 




(5R,6S)-Cryptocap $\sin$-5,6-e poxi de (5)<smiles>CC(/C=C/C=C(C)/C=C/C(=O)[C@@]1(C)CCCC1(C)C)=C\C=C\C=C(C)\C=C\C=C(C)\C=C\[C@]12O[C@]1(C)C[C@@H](O)CC2(C)C</smiles>

3'-Deoxycapsanthin-5,6-epoxide (6)<smiles>CC(/C=C/C=C(C)/C=C/C(=O)[C@@]1(C)C[C@@H](O)CC1(C)C)=C\C=C\C=C(C)\C=C\C=C(C)\C=C\[C@@]12O[C@]1(C)CCCC2(C)C</smiles>

(5S,6R)-Cryptocap $\sin$-5,6-e poxide (7)<smiles>CC(/C=C/C=C(C)/C=C/C=C(C)/C=C/C12O[C@]1(C)C[C@@H](O)CC2(C)C)=C\C=C\C(C)=C\C=C\[C@]12O[C@]1(C)CCCC2(C)C</smiles>

(3S,5R,6S, 5' R,6'S)-ß-Cryptoxan thin-5,6,5',6'-diepoxide (8)<smiles>CC1=C(/C=C/C(C)=C/C=C/C(C)=C/C=C/C=C(C)/C=C/C=C(C)/C=C/C2=C(C)C(C)(C)CCCC2(C)C)C(C)(C)C[C@H](O)C1</smiles>

$\left(3 R, 5^{\prime} R, 6\right.$ 'S)-ß-Cryptoxanthin-5',6'-epoxide (9)

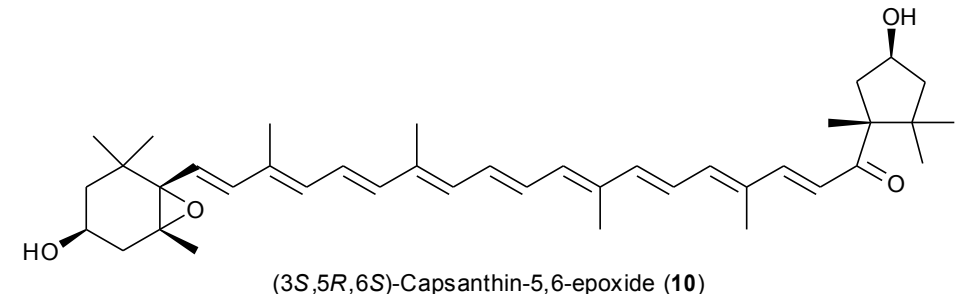

(3S,5R,6S)-Capsanthin-5,6-epoxide (10) 

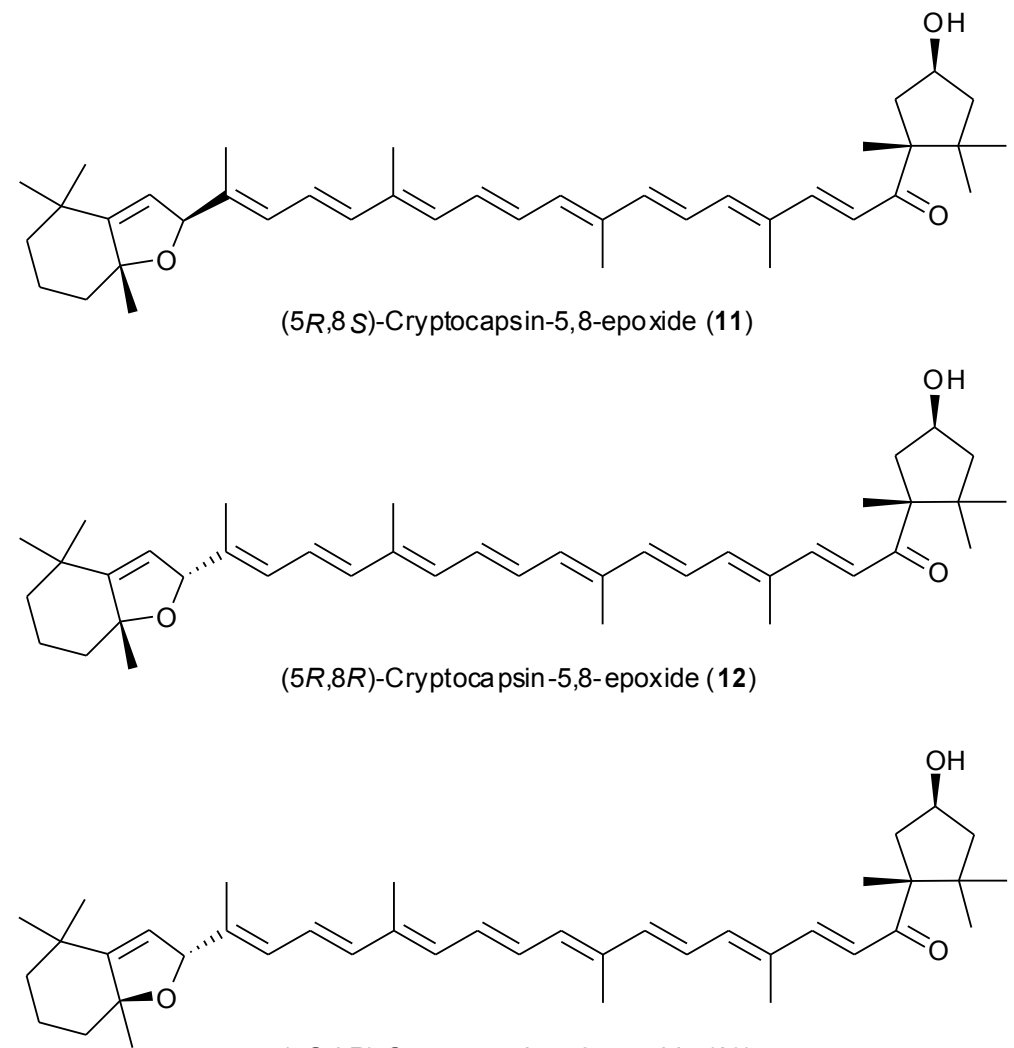

(5S,8R)-Cryptocapsin-5,8-epoxide (13)

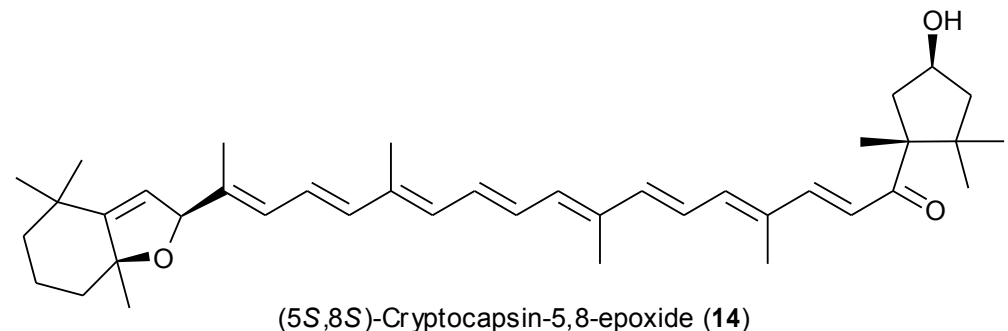

(5S,8S)-Cryptocapsin-5,8-epoxide (14) 
Figures:

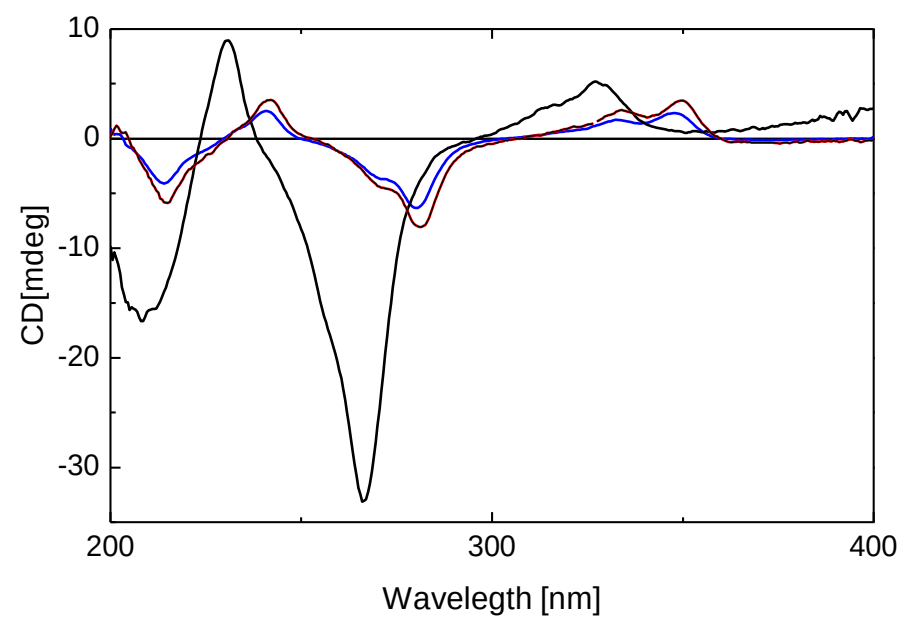

Figure 1. ECD spectra of $\left(5 R, 6 S, 3^{\prime} S, 5^{\prime} R\right)$-cryptocapsin-5,6-epoxide (5, red) $\left(3 R, 5 R, 6 S, 5^{\prime} R\right)$ $3^{\prime}$-deoxycapsanthin-5,6-epoxide (6, blue) and $\left(3 S, 5 R, 6 S, 5^{\prime} R, 6^{\prime} S\right)$ - $\beta$-cryptoxanthin-5,6,5',6'diepoxide $(\mathbf{8}$, black).
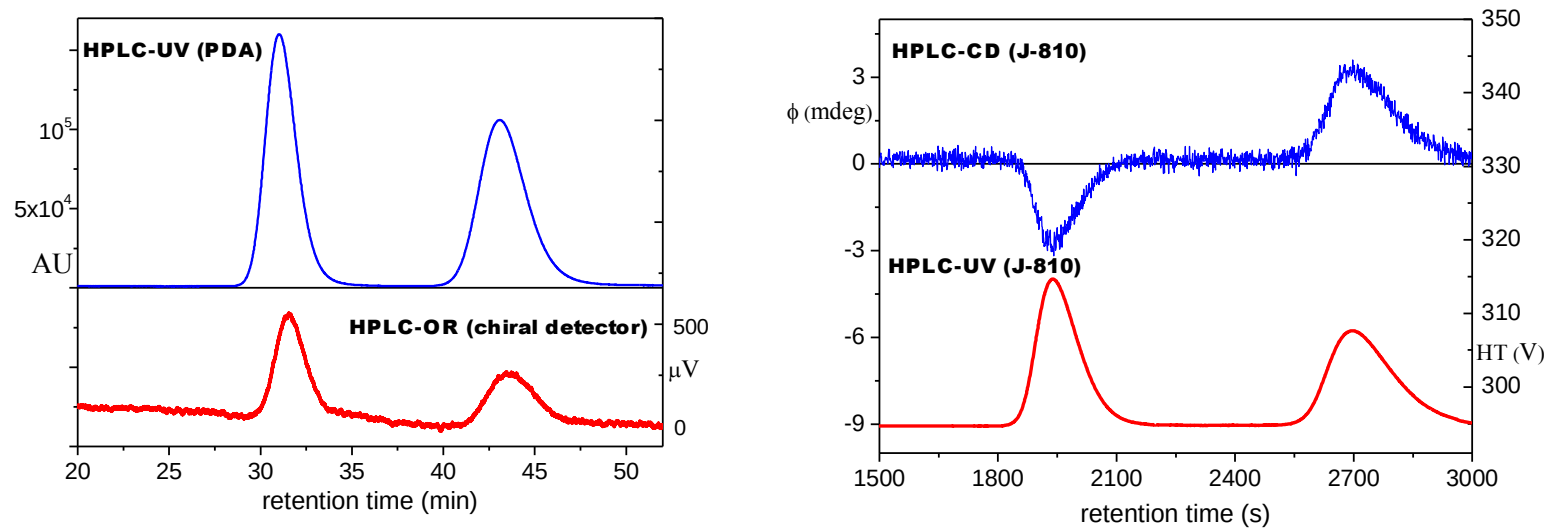

Figure 2. a) HPLC-UV (upper blue curve) and -OR (lower red curve) chromatograms of the separated $\left(5 R, 6 S, 3^{\prime} S, 5^{\prime} R\right)$ - and $\left(5 S, 6 R, 3^{\prime} S, 5^{\prime} R\right)$-cryptocapsin-5,6-epoxide diastereomers $(\mathbf{5}, \mathbf{7})$ monitored at $480 \mathrm{~nm}$ (Chiralcel OD, $n$-hexane/EtOH 50:50). b) HPLC-ECD (upper blue curve) and -UV (lower red curve) chromatograms of the separated $\left(5 R, 6 S, 3^{\prime} S, 5^{\prime} R\right)$ - and $\left(5 S, 6 R, 3^{\prime} S, 5^{\prime} R\right)$-cryptocapsin-5,6-epoxide diastereomers monitored at $280 \mathrm{~nm}$ with $\mathrm{J}-810$ spectropolarimeter (Chiralcel OD, $n$-hexane/EtOH 50:50). 


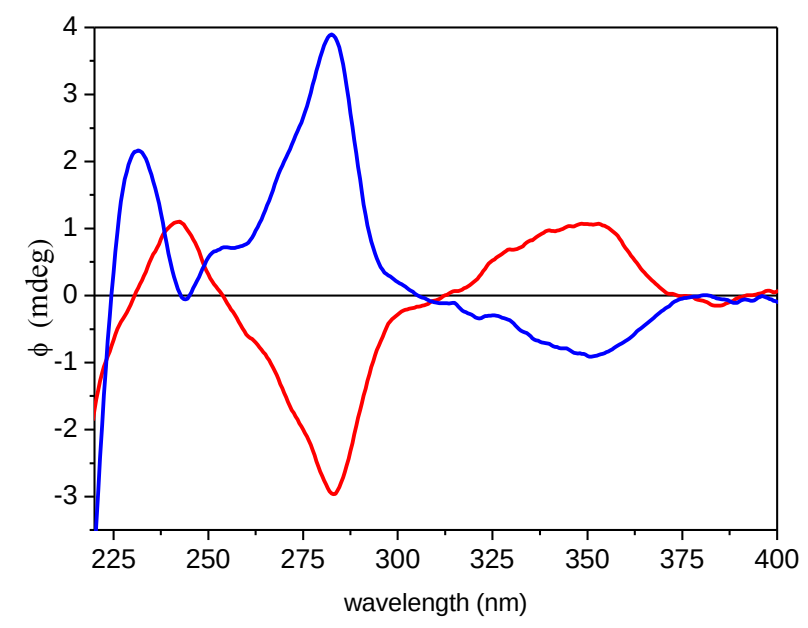

Figure 3. HPLC-ECD spectra of $\left(5 R, 6 S, 3^{\prime} S, 5^{\prime} R\right)$-cryptocapsin-5,6-epoxide (5, red, firsteluting distereomer) and $\left(5 S, 6 R, 3^{\prime} S, 5^{\prime} R\right)$-cryptocapsin-5,6-epoxide (7, blue, second-eluting diastereomer).

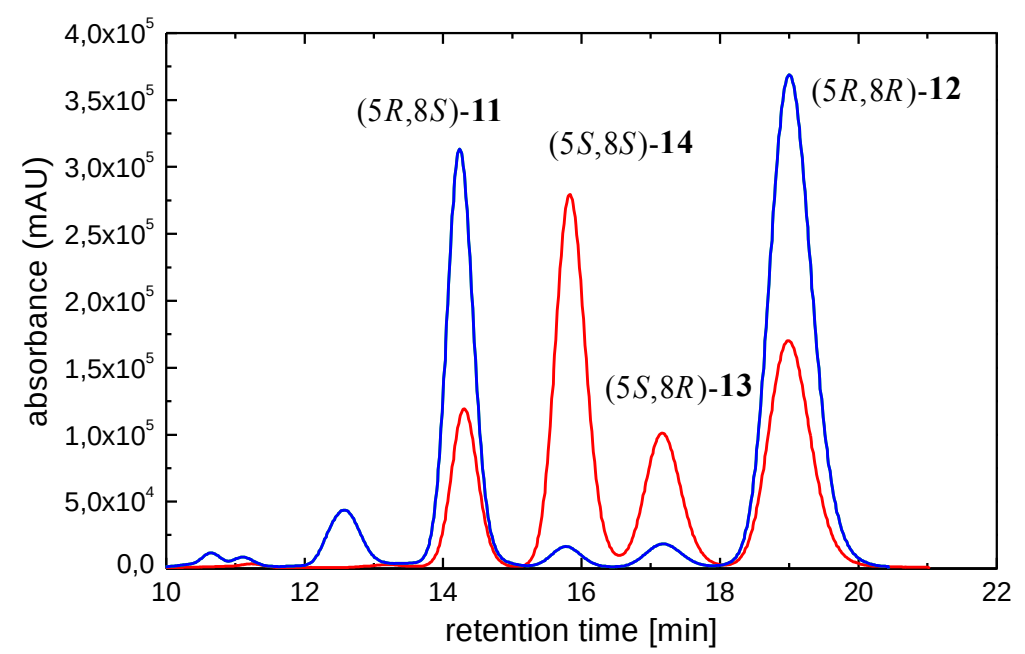

Figure 4. Overlapped HPLC-UV traces (463 nm) of natural [blue, $\left(5 R, 8 S, 3^{\prime} S, 5^{\prime} R\right)-\mathbf{1 1}$, $\left.\left(5 R, 8 R, 3^{\prime} S, 5^{\prime} R\right)-12\right]$ and semisynthetic stereoisomeric mixture of cryptocapsin-5,8epoxides [red, $\left(5 R, 8 S, 3^{\prime} S, 5^{\prime} R\right)-\mathbf{1 1},\left(5 R, 8 R, 3^{\prime} S, 5^{\prime} R\right)-\mathbf{1 2},\left(5 S, 8 R, 3^{\prime} S, 5^{\prime} R\right)-\mathbf{1 3},\left(5 S, 8 S, 3^{\prime} S, 5^{\prime} R\right)$ 14] with Chiralpak IC column ( $n$-hexane/EtOH 80:20); 


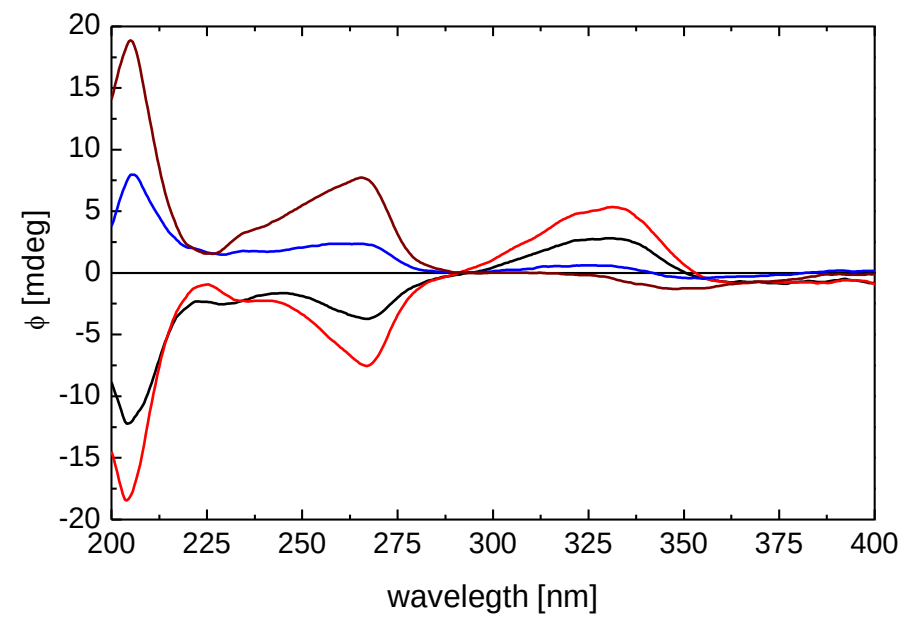

Figure 5. HPLC-ECD spectra of diastereomeric cryptocapsin-5,8-epoxides in $n$ hexane/EtOH 80:20: black: (5R8S,3'S,5'R)-11, first-eluting; red: $\left(5 S 8 S, 3^{\prime} S, 5^{\prime} R\right)-14$, second-eluting; blue: ( $\left.5 S 8 R, 3^{\prime} S, 5^{\prime} R\right)-\mathbf{1 3}$, third-eluting; brown: $\left(5 R 8 R, 3^{\prime} S, 5^{\prime} R\right)-\mathbf{1 2}$, fourtheluting diastereomer.

\section{Schemes:}

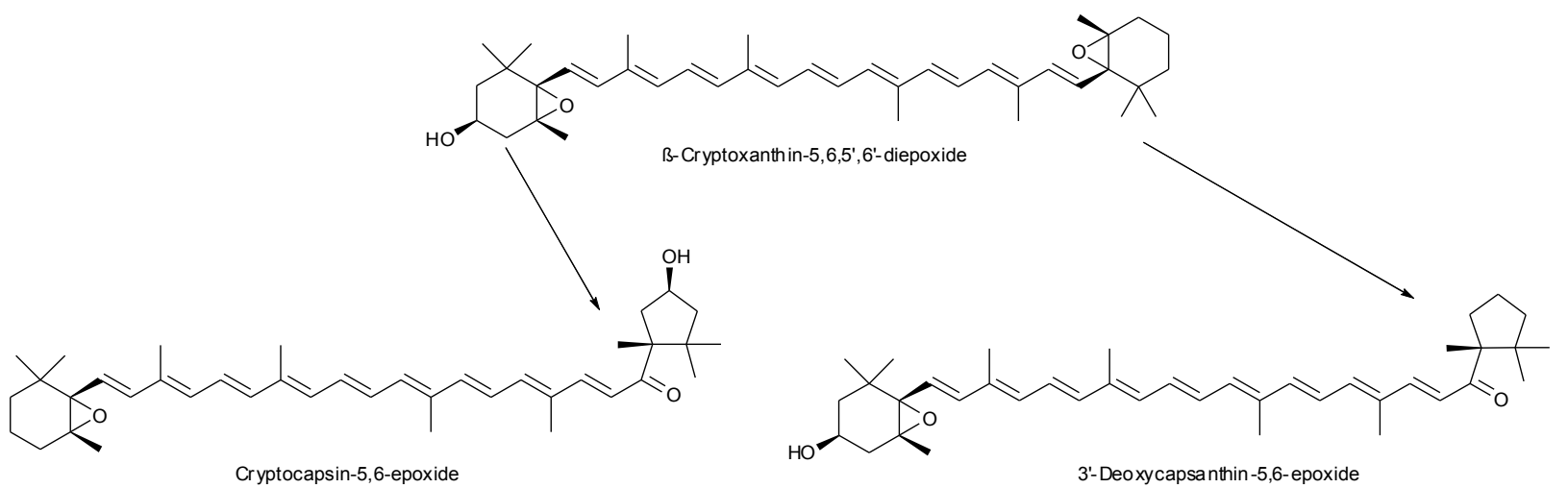

Scheme. 1. Formation of cryptocapsin-5,6-epoxide (5) and 3'-deoxycapsanthin-5,6-epoxide (6) from $\beta$-cryptoxanthin-5,6,5',6'-diepoxide (8) 
For the Table of contents:

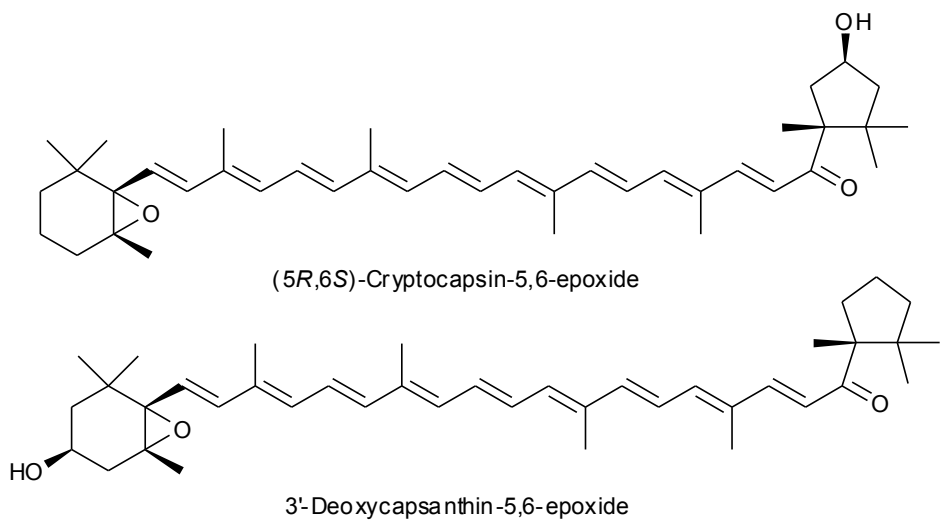

